\title{
Efficient Fuel Handling and Management in Port: Context Bangladesh
}

\author{
Razon Chandra Saha \\ Center for Higher Studies and Research, Bangladesh University of Professionals, Mirpur Cantonment, Dhaka 1216, Bangladesh
}

\begin{abstract}
In the last two decades, the supply and demand of fuel in Bangladesh increased enormously because of her economic growth. Likewise, energy and power require helping the industry and basic supplies to the citizens. Recent development of electric power industry, is essential to arrange the necessary facilities at seaport and its further transportation to the consignee premises by applying JIT (just-in-time) approach inevitably. Driven in particular, innovation is required in the prime ports Chittagong and Mongla, what's more, in newly established Payra port. In addition, regional demand especially from Nepal, Bhutan and Seven Sisters of India for importing fuel through Bangladeshi seaports or pertaining intermodal freight transportation of containerized fuel or tanktainer that cloaked up the derived demand of increasing seaport facilitates in Bangladesh. Another factor that will influence the importing and handling of fuel is the environmental compliance and stringent environmental regulations enacted by IMO (International Maritime Organization), hereby, necessary steps to be taken by port authority or government accordingly. Emerging opportunities, in addition to traditional fuel management at port, coal, LPG (liquefied petroleum gas) and LNG (liquefied natural gas) are the new products for Bangladesh and its neighbors as growing demand of receiving in Bangladeshi ports in a big volume progressively. This paper aims to explore the role of port authorities in the process of developing port and intermodal infrastructure and others to mitigate the uprising demand of fuel handling in port protected area and quick transfer of fuel to the final destination.
\end{abstract}

Key words: Fuel, industry, just-in-time, intermodal, tanktainer, IMO.

\section{Introduction}

Fuel handling and management at seaport (herein after "port") is a key issue for an import based country and its importance is increased highly to mitigate the growing energy requirements of industry and people. In the last two decades, the supply and demand of fuel in Bangladesh increased enormously as because of her economic growth also energy and power requirements to help the industry and basic supplies to the citizens. Globalization, industrial development and large population in Bangladesh derived the demand of fuel to run the country where domestic productions are not sufficient and it is essential to import fuel via ports. Greatly, innovation is the way of adapting in the new environment at the stage of demand that derived naturally or concentration of human being to cope

Corresponding author: Razon Chandra SAHA, Ph.D., researcher, research fields: intermodal freight transportation, shipping and logistics. with the age and trends of globalization [1]. Driven in particular, innovation is required in the prime ports Chittagong and Mongla, what's more, in newly established Payra port. In addition, regional demand especially from Nepal, Bhutan and Seven Sisters of India for importing fuel through Bangladeshi ports or pertaining intermodal freight transportation of containerized fuel or using tanktainer or railway fuel wagon that cloaked up the derived demand for increasing port facilitates in Bangladesh. Connectively, the growth [2] of intra-regional trade and the expected growth of containerized transport in Asia are demonstrating the need of Intermodal freight transportation in all likelihood.

Importantly, deficiency of energy is a major problem in the process of economic development in Bangladesh. Due to non-exploration of new energy field and alternative energy, it is necessary to import energy as well as fuel. To make availability of fuel through import from abroad, port access is a vital 
point that needs to consider highly. Moreover, improving port capacity for handling fuel and further distribution network towards the industry, transport fueling points and all over the country has potential to develop the country dynamically. Mention that port makes the country vibrant in reducing the cost of fuel and saving time but that depends on the integrated fuel handling system of a port and its inland distribution network.

Preliminary, port facilities in Bangladesh are stated and how fuel is handling and managing including distribution to the inland transport networks in those ports are attributed briefly. Mention that Bangladesh has geographical advantages in the Bay of Bengal and maritime business logistics opportunities are studied to do port transport business of fuel (POL (petroleum, oil and lubricants), coal and others) with the neighbors regionally and internationally. After that research found some innovations in fuel handling at port and transportation that explored in Section 6. Furthermore, related literature on fuel handling at port, innovation and transportation are gathered in the literature review section that followed by the CSFs (critical success factors) in port management Section which is highly connected with the qualitative research findings and analysis Section 9. Just after, research is concluded by summarizing the works that performed as per objectives. Finally, it reflected the future directions that will help the port authorities, government, stakeholders, business groups, port users, researchers and others to understand the maritime affairs at port to handle the fuel efficiently.

Prominently, Bangladesh is a lucrative place in the Asia for doing future trade and investment where energy is a factor. To produce sufficient energy for the industry and people, fuel importation is essential where port facilities are great factor to supply the raw materials for power plant and finished POL to the consumer. Emerging opportunities, in addition of traditional fuel management at port, coal, LPG (liquefied petroleum gas) and LNG (liquefied natural gas) are the new products for Bangladesh and its neighbors as growing demand of receiving in Bangladeshi ports in a big volume progressively. This paper aims to explore the role of port authorities in the process of developing port and intermodal infrastructure and others to mitigate the uprising demand of fuel handling in port protected area and quick transfer of fuel to the final destination.

\section{Research Methodology}

To unfold, many social scientist adopt a qualitative research method where researcher self-assessment and situating the topic in a socio-historical context along with personal beliefs that identified the topic of interest or its importance to the welfare of the society [3]. The author gets such motivation and feels interest to do analytical research in fuel management of Bangladesh to sustain in the trade world competitively. Recent development of electric power industry and planning for coal, furnace oil and other fuel based power plant, industrial development, household energy requirements are the key factors to import fuel from abroad via port and it is the specific current issue in Bangladesh. To follow the guidelines of Neuman [3] and address the specific current issue fuel, this research selected qualitative research methodology arguably. Mention that advanced technological circumstances, market imperatives and efficiency are being innovative in various economic sectors, therefore, applied research and developments in logistics and supply chain management are crucial greatly [4]. In designing the research and questionnaire, the author had visited the two principal ports in Bangladesh and shared the research aims with the port authority, port users and others. Afterwards, a key component of this study is to identify the barriers and CSFs at ports in handling fuel and its proper management in Bangladesh. In this connection, the chosen qualitative research methodology offered to the expert in port sector by email and courier/post office. 
In addition, this research maintained the ethical matters in collecting data from the field and coded the name of respondents instead of publishing the name as per commitments in the invitation letter. Relatedly, Kumar [5] argued to establish an overall code of ethics during data collection and adding as reference in writing the findings in the research paper. In this connection, during in-depth interview with the respondent, in the midway, further questions were not asked that would distract or harmful for the respondent. Furthermore, critical answer was removed and not quoted directly in the paper. This research faced extensive limitations in getting the full data of fuel import in Bangladesh where import by government statistics is available in the source of BPC (Bangladesh Petroleum Corporation) and private import data are absent fully. Moreover, fuel handling quantity in major ports Chittagong and Mongla are not available. Lastly, minimum responses were participated in the qualitative survey and invited persons were not interested to provide answer against the research questionnaire.

Another factor influenced the author, instead of existing data related to fuel handing at port in Bangladesh, all respondents were requested to see the future or trends of using fuel in Bangladesh also the fuel estimation for power plants and domestic usage like LPG usage in cooking at industry and households. Maximum respondents had voted thanks for the initiative of this research for fuel handing and management at port in Bangladesh.

\section{Seaport Facilities in Bangladesh}

Bangladesh has three international standard seaports which are playing lively roles in doing import-export trade that resulted economic growth of the country. Mention that country is renowned for readymade garments export to earn foreign exchange and fuel import to mitigate the energy demand of industry, transport and domestics household usages endlessly. In addition, off-docks, ICD (inland container depot), IRD (inland river terminal), and RICT (riverine inland container terminal) are available all over the country. In order to manage and operate the imported fuel oil via ports, BPC [6] has good network of rail, road and waterways that comprises railhead depots, riverine depots also inland oil depots as integrated supply chain to serve the nation prestigiously. Here, most of the cargo and containers are performing for Bangladesh only with the limited edition of serving India, Nepal and Bhutan regionally. Details of the ports and fuel handling facilities are described in bellows.

\subsection{Chittagong Port}

The Chittagong Port, under the management of CPA (Chittagong Port Authority) [7] is the principal port of Bangladesh who handling approx. $92 \%$ of seaborne trade of the country and mounting the great importance in the national economy. To handle the fuel, Chittagong port has 3 nos Dolphin Jetty for POL with the facilities of inland coaster and tanker vessel berthing at the jetty and pontoon [8]. At the outer anchorage, mega vessels or tankers are unloading the fuel to lighter vessel. The port has VTMIS (vessel traffic management information system) for ensuring the maritime safety and security of navigation for all incoming and outgoing vessel in the port protected area. Traditionally, this port is maintaining its efficiency and reputation among the Asian ports with a good standing in the port world. Remarkably, Chittagong port is the economic gateway of south Asia in providing necessary services and facilities to the port users efficiently and effectively at competitive price. On the other hand, ADB (Asian Development Bank) [9] reported that Chittagong port suffers from the problems relating to limited accessibility for larger ships, gaps in facilities, variable operational efficiency and low connectivity in between port and hinterland modes of rail, road and inland waterways. However, port is trying to achieve international standard efficiency and productivity by providing and 
facilitating excellent services to the port users/stakeholders timely. Furthermore, port authority is performing to improve the efficiency of other ports, inland nodes and financing in the infrastructural development of inland distribution and intermodal network of the country.

\subsection{Mongla Port}

Mongla port is the 2nd seaport in Bangladesh. After the Chittagong port, this port has all modern facilities to handle the import export trade especially handling fuel (LPG, coal and other POL) and supply to the power plants and industry [10]. However, this port is underutilized because of its poor connection with the major cities and industrial areas. Having the opportunity to spare the unutilized capacity, Mongla port is ready to serve the neighbors by renovating the road \& highways and infrastructural development of railway network from the port. Mongla port is trying to assist the Chittagong Port to reduce the pressure of cargo handling where innovations are required to attract the trader and need to improve the port facilities to cater the international business. This study found the potentiality of Mongla port to provide the access to India, Nepal and Bhutan directly for doing port transport business.

\subsection{Payra Port}

In the aim of facilitating annual seaborne trade growth on average $9.2 \%$ of Bangladesh, government has established 3rd seaport Payra to accommodate the foreseeable trade volume and support the neighbors in accessing the port facilities in the South Asian region [11]. Government has taken Short, Mid \& Long Term Plan to develop a state of art modern sea port by 2023. Greatly, potentiality of newly established Payra port is looking forward to build transport network as alternative of deep seaport in the region. In addition, port will arrange the supply of coal to the nearby coal fired power plant. Having in mind, port will connect with the capital city Dhaka and neighbor countries Nepal, Bhutan and India by rail network that will assist to promote the intermodal network.

\subsection{Off-dock, ICD and ICT}

BIWTA (Bangladesh Inland Water Transport Authority) and CPA jointly built first RICT in Bangladesh named PICT (Pangaon inland container terminal) [12] in 2013 that expected to play a positive role in the country's economic development by opening up a new horizon in the transportation of exported and imported goods through waterways and it is followed by another private RICT in Munshiganj by Summit Group in 2016. Both RICTs are planned to reduce the pressure of transporting cargo by truck and container in Dhaka-Chittagong highway and representing Chittagong port near the capital city Dhaka for assisting shipper consignee to catch the shipment schedule timely. Furthermore, Chittagong Custom House [13] listed 14 no's off-dock in Chittagong for import export activities, in addition, managing Dhaka ICD, shipper premises of all over the country also specialized cargo at anywhere in the quota of others. In fact, Chittagong port does not handle any export stuffing of container where off-docks are doing excellent maritime logistics support to the port.

In the port industry, vessels are getting bigger, and economic ebbs and flows constantly alter the volume of cargo [14]. In this connection, ports are expected to adapt in the growth that is exciting to port users also for the port authorities to collaborate with the government or private investors to enhance the capacity and improve the port efficiency by installing latest handling equipments and train the port operator as per world standard and indicators related to port development. All of the Bangladeshi ports are in a position and have the plan to improve their efficiency by PPP (public private partnership) and international collaboration with the renowned terminal operators of the world. 


\section{Fuel Handling, Management and Distribution}

There are two key factors that are demanded the transport for carrying the cargo and passengers, particularly, economic growth by industry and population growth. Both factors are creating the situation to produce more energy as well as fuel that bounded to mine more or import fuel from abroad. In the sense of growth, WEC (World Energy Council) [15] forecasted that, over the next four decades, the global transportation sector will face unprecedented challenges related to demographics, urbanization, pressure to minimize and dislocate emissions outside urban centers, congestion of aging transport infrastructure and growth in fuel demand. Supply and demand data of liquid bulk, dry bulk coal, POL and others containerized cargo as fuel is totally absent in Bangladesh and port statistics are not showing any data in handing fuel vessels, quantity in a whole. However, this study focused on the below fuel items as cargo that are handling in ports of Bangladesh:

To handle a certain amount of freight, port and yard infrastructure of fuel terminal for handing coal, LPG and LNG are under process and having a plan to establish through PPP at Masheshkhali under Chittagong port and nearby Mongla port to mitigate the derived demand for power plant, industry and domestic uses. Furthermore, newly established Payra port has exclusive plan to handle mega vessels of fuel in the integrated terminal to mitigate the demand of energy of Bangladesh as well specialized handling POL berth and jetty for the neighbors India, Nepal, Bhutan and China.

Meanwhile, BPC [6] updated that fuel importation is increasing steadily but projected to import less oil in future but it will make more percentage in Coal, LPG and LNG. In this connection, master plan has taken to build specialized port jetty/terminal in Maheshkhali under the management of Chittagong port and Payra port through PPP to assist the public and private power plants in producing electricity that will help to reduce the quantity of oil import [16].

In 1980, first time coal imported that stopped in 2008 dramatically, again it was started in 2009 and rose the figure significantly [17]. For recent development of power sector, government has approved the coal fired power plant that will increase the import of coal and mega vessel will be arrived in Bangladeshi ports soon.

Table 1 Types of the fuel that handling in Bangladeshi ports.

\begin{tabular}{|l|l|l|l|l|}
\hline Types of the fuel & Details & Import or export & Destination & Remarks \\
\hline Crude Oil & SN-150, SN-500 SBS-150. & Import & $\begin{array}{l}\text { Eastern Refinery Limited } \\
\text { in Chittagong. }\end{array}$ & Finished product. \\
\hline Refined Oil & Diesel, Gasoline Jet A-1, Kerosene. & Import & $\begin{array}{l}\text { Listed depot in all over } \\
\text { the Bangladesh. }\end{array}$ & $\begin{array}{l}\text { Further to selected oil } \\
\text { depot via rail, road and } \\
\text { waterways. }\end{array}$ \\
\hline LPG & $\begin{array}{l}\text { Preliminary, importing by medium } \\
\text { type vessel and transferring to the } \\
\text { shore by pipeline. }\end{array}$ & Import & $\begin{array}{l}\text { Chittagong and Mongla. } \\
\text { for households and } \\
\text { industry. }\end{array}$ \\
\hline LNG & $\begin{array}{l}\text { Planned for power plant and mega } \\
\text { vessel will bring in the specialized } \\
\text { terminal that is under construction. }\end{array}$ & Import & $\begin{array}{l}\text { Selected power plants } \\
\text { and other purposes for } \\
\text { industry. }\end{array}$ & $\begin{array}{l}\text { Under process by the } \\
\text { government through PPP. }\end{array}$ \\
\hline Coal & $\begin{array}{l}\text { Planned to bring mega vessel. } \\
\text { Currently, importing by private sector. } \\
\text { Lighter vessels are using to unload } \\
\text { mother vessel at outer anchorage of } \\
\text { Chittagong and Mongla port. }\end{array}$ & Import & $\begin{array}{l}\text { Selected power plants } \\
\text { and other purposes for } \\
\text { industry. }\end{array}$ & $\begin{array}{l}\text { Deep sea terminal for coal } \\
\text { is planned and under } \\
\text { process. }\end{array}$ \\
\hline $\begin{array}{l}\text { Containerized POL } \\
\text { and tanktainer. }\end{array}$ & $\begin{array}{l}\text { Import is managing in Chittagong and } \\
\text { Mongla port. }\end{array}$ & Import & $\begin{array}{l}\text { Somewhere intermodal is } \\
\text { using to Dhaka ICD and } \\
\text { PICT. }\end{array}$ & $\begin{array}{l}\text { Continuing. Expecting } \\
\text { growth by this import. }\end{array}$ \\
\hline $\begin{array}{l}\text { Naphtha and natural } \\
\text { gas condensate. }\end{array}$ & $\begin{array}{l}\text { Eastern Refinery Limited in } \\
\text { Chittagong is producing as by product } \\
\text { and exporting accordingly. }\end{array}$ & Export & Foreign country. & \\
\hline
\end{tabular}




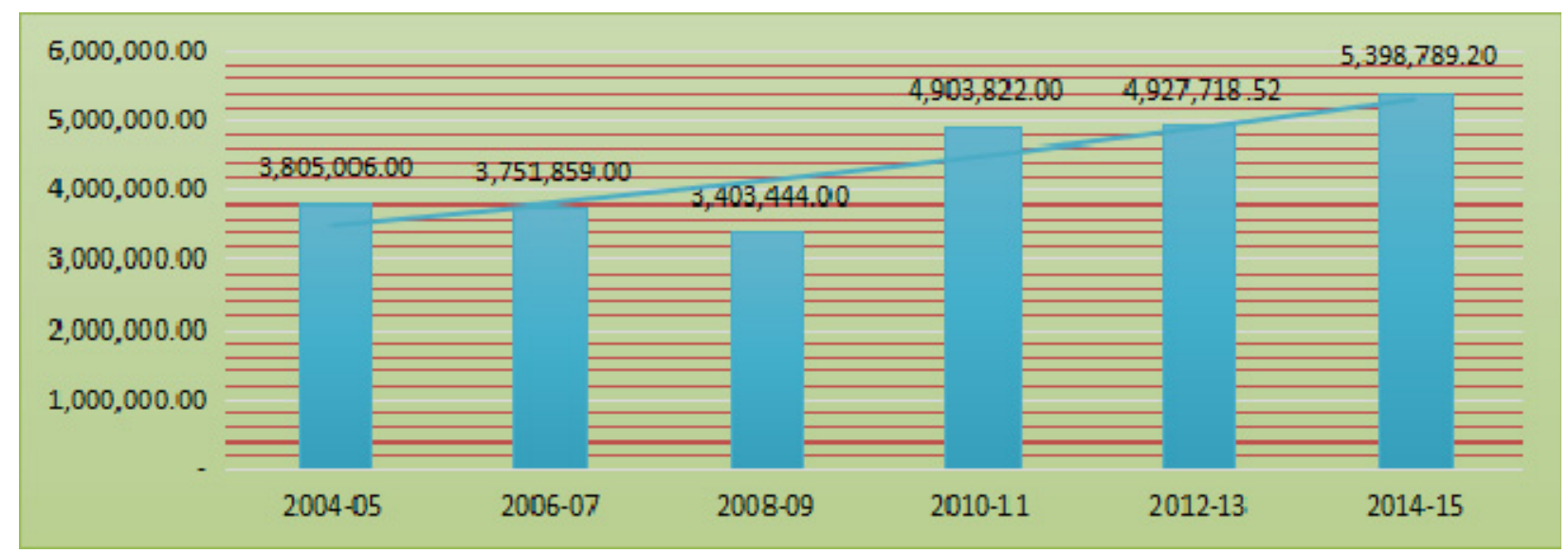

Fig. 1 Handling of fuel oil in metric ton by BPC as import for Bangladesh. Source: BPC 2016 [6].

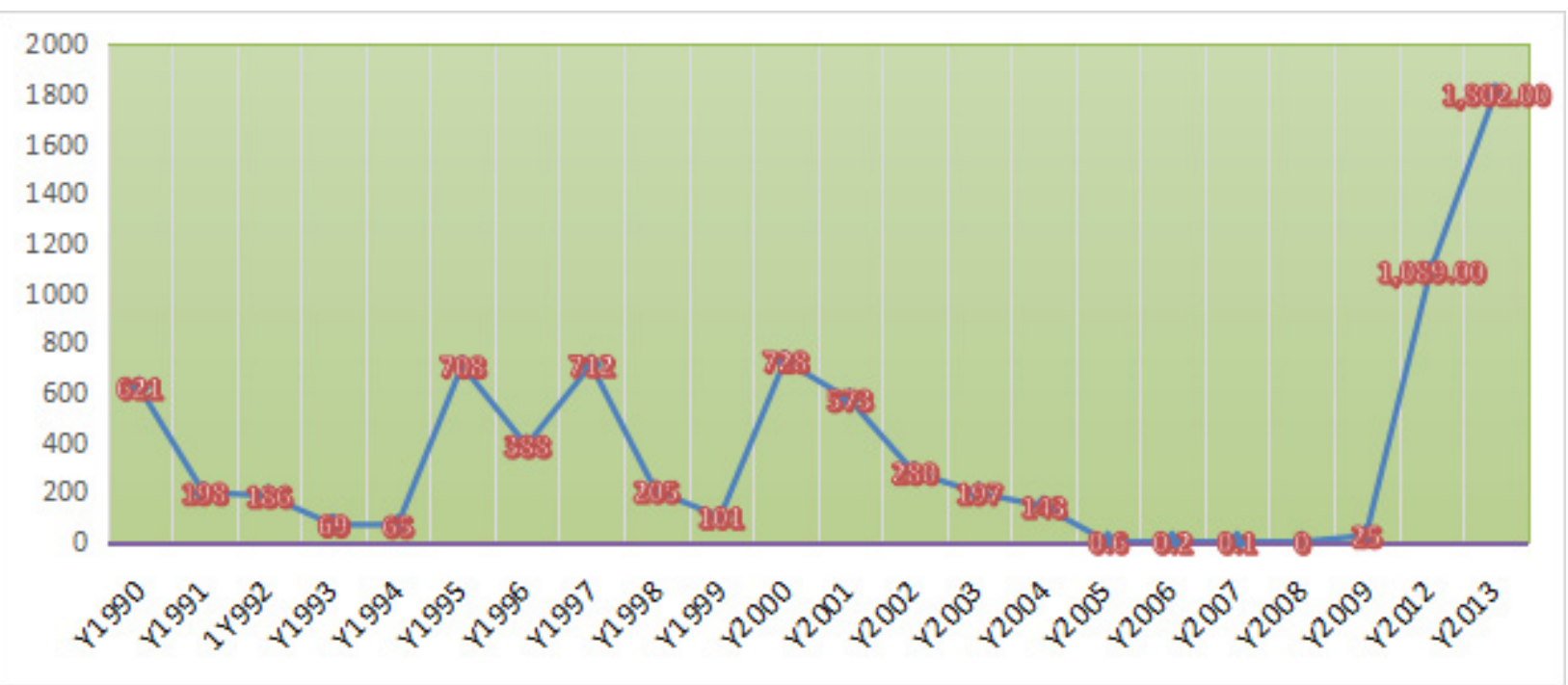

Fig. 2 Coal import in Bangladesh (in thousand short tons). Source: Indexmundi 2016 [17].

In line with previous trends of oil, MOF (Ministry of Finance) [18] forecasted the future demand of coal and by 2030 it will be $50 \%$ in producing power where maximum portion will be imported from abroad. Inland waterways connection with the ports is vital for quick transfer of fuel to the final or nearby destination. Fortunately, Bangladesh has excellent inland connections and tanker vessels to do this task but it is not possible to do directly because of BPC's operation strategy and location of the refinery and full controlling of government based organization. Bangladesh is sloping to import fuel gradually while dependence on imported fuel will be increased from $10 \%$ (was in 2010) to $70 \%$ (will be in 2030) as per estimation and upcoming projects of power generation like coal-based power plants, LNG fuel and nuclear power plants [16]. In this connection, a large number or quantity of coal, LNG, uranium fuel will be unloaded in Bangladeshi port's terminal to supply the raw materials in power plant. In addition, LPG terminal will be established with integrated pipeline in the major urban cities and manufacturing industry to reduce the pressure on domestic's production of natural gas and coal.

\section{Maritime Logistics Business Opportunity}

Bangladesh is potential to do maritime logistics business in the region by taking the geographical advantages in the Bay of Bengal. Economic criteria prevailed over the political or territorial matters that 
helped to take investment decision to serve foreign trade where competitive logistics services are required inevitably. In here, energy is a great factor in Bangladesh for economic development as well as daily requirements of citizen remarkably. The situation and context of abilities to purchase power and energy even is by importing for catering the trade and consumption in daily life. There are huge opportunity in doing maritime logistics business regionally and internationally by providing port transport the neighbors and it is derived demand of those countries who are basically landlocked and facing the insufficient access to the port.

Although neighbors have own fuel supply plan but to reduce the shipping and transport cost in the South Asia, Bangladeshi ports are so lucrative that resulted the opportunity of Maritime logistics business. In this connection, integration among the foreland, ports and

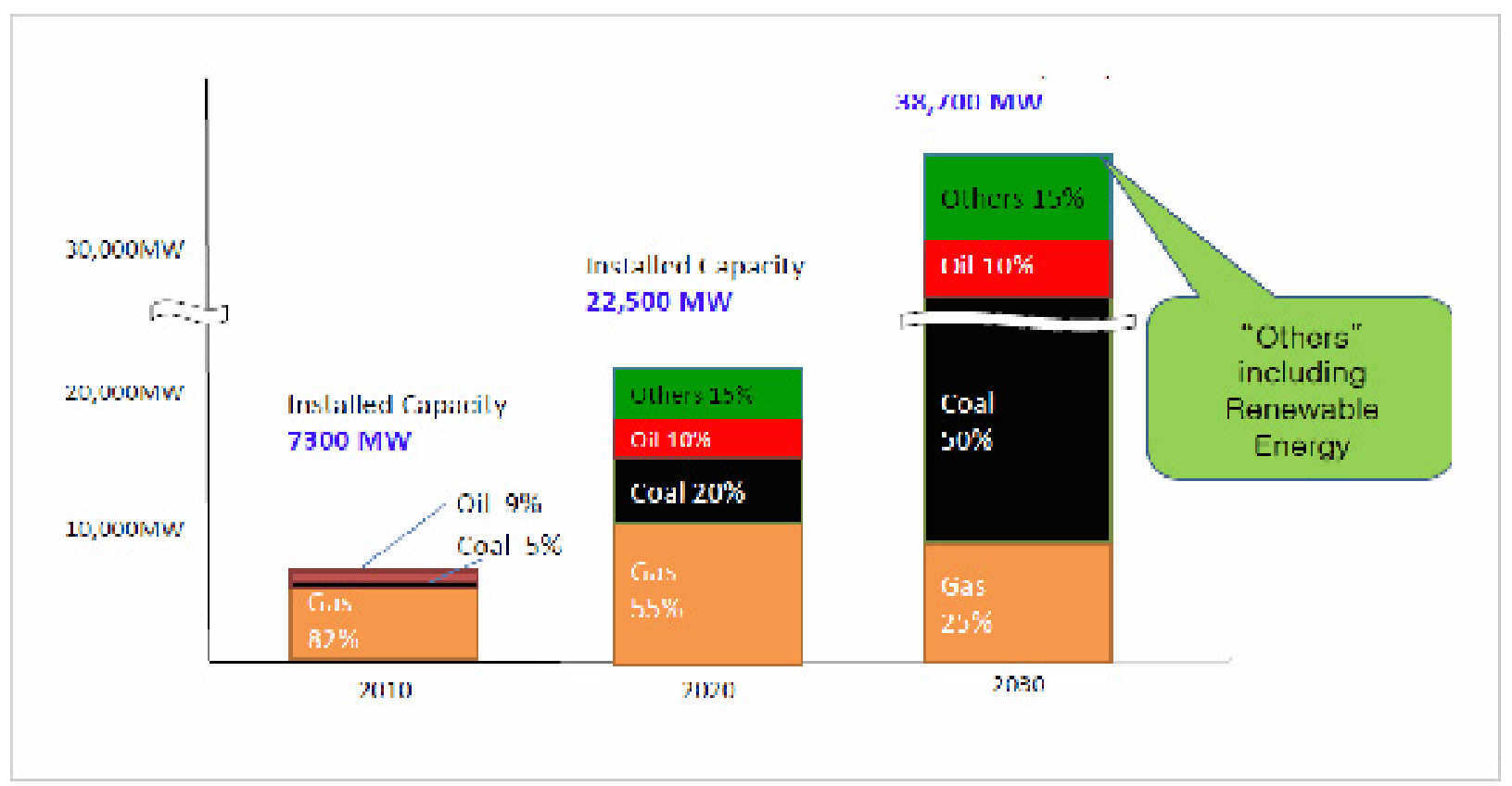

Fig. 3 Projection of using fuel (coal and oil) in generating power in Bangladesh [18].

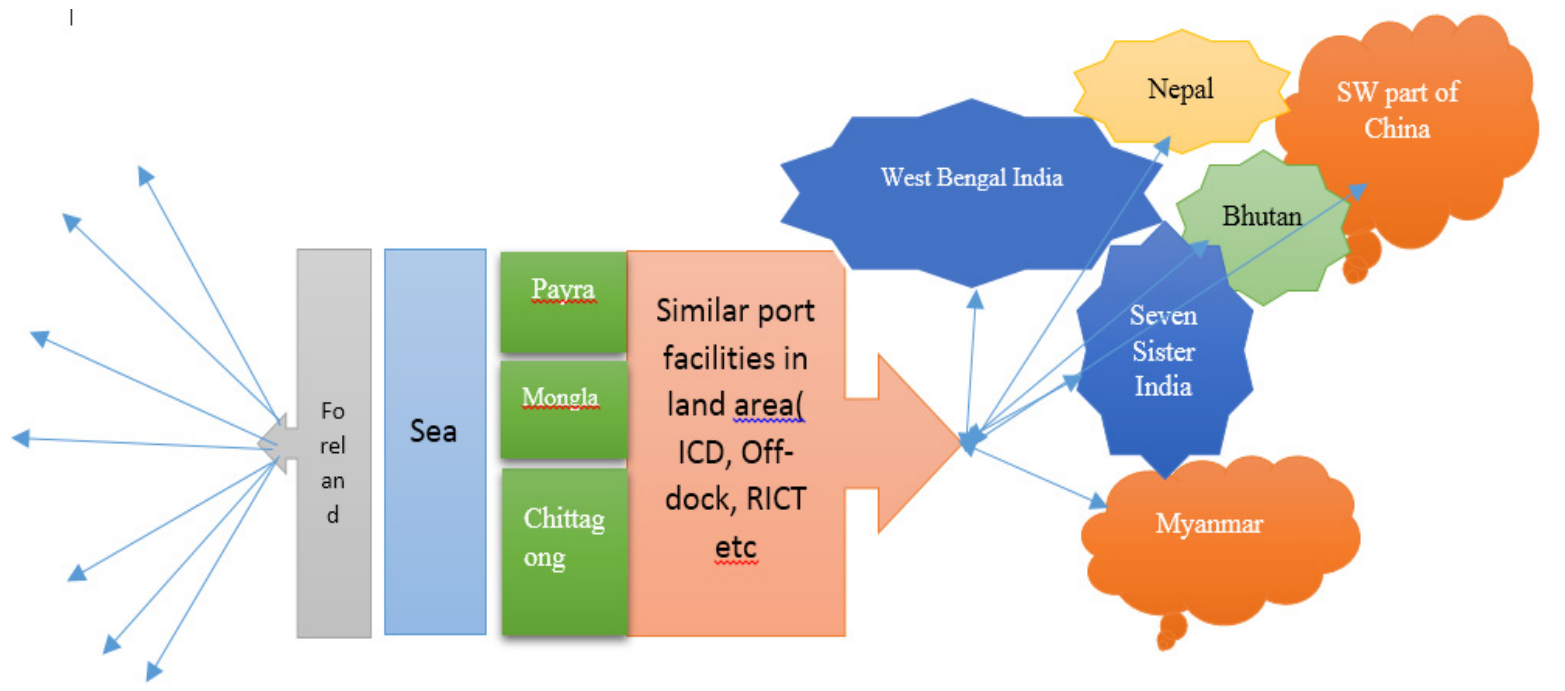

Fig. 4 Foreland and hinterland of Bangladeshi ports [19]. 
hinterland will help to create shipping networks and transport facilities that is absolutely international for doing port transport business [20, 21]. Present shipping world is facing a volatile environment, dynamic markets and challenges by new environmental and social consideration, particularly, users are demanding innovative solutions to add value as well as resilience into the future maritime logistics industry exclusively in the operating ports and its associated organizations [22]. They added that globalization, achieving market place and rapidly changing technology are three major factors in the transition of port sectors that affected significantly. To enable the regional growth in South Asia for mutual benefit and building the partnership in the energy and power sector, Bangladesh has to play a key role in offering the neighbors in managing fuel (POL, coal and others liquid bulk and containerized fuel) at port and its further transportation to the respective country timely and in minimum costs to make popular ports in the region. Accessing the Bay by land locked regions such as India's NE part, Southern China, Nepal and Bhutan would add huge value in their development and economic growth [23]. In fact, port investment decision depends on the port productivity or vibrant future for expanding the capacity for utilization and financial performances [24]. In here, decisions are helping to the private investor to invest in the profitable port sector. Mention that port system is evaluated at each port component that based on the long term profitability, potential, moreover feasibility study of freight, trade and industry in the vicinity of the port hinterland.

\section{Innovations in Fuel Handling and Inland Transportation}

Impressively, innovation is the most important driver of firm competitiveness in advanced world economy [4]. From the content analysis of secondary sources and qualitative research interview, research found some innovations for handling and management of fuel at port and further distribution by inland transportation. Among them, this paper discussed and analyzed three innovations which are multi-core pipeline [22], tank container or tanktainer, coal containerization [25] and synchromodal [26].

\subsection{Multi-core Pipeline}

Multicore pipeline is environment friendly, safe and uninterrupted mode of transport, decreasing the traffic congestion, efficient use of space and strengthening fuel cluster also suitable for chemicals [22]. This research found the feasibility of constructing multi-core pipeline in the mid space of Dhaka-Chittagong High way that will help to establish LPG bottling plant in nearby Dhaka instead of Chittagong for reducing the transport cost. Furthermore, it will assist the port authority in easy handling of fuel (LPG and LNG) and nonstop transfer of fuel from sea to shore efficiently.

\subsection{Tank Container or Tanktainer}

Currently, tanktainer is handling in the port in a limited edition where Bangladesh has the opportunity to bring the fuel by tanktainer and send to the transport network. Due to the recent revolution of intermodal freight transportation through intermodal modes, tanktainer transportation will help the consignee to import small scale of cargo instead of renting mega vessel and it is very useful to all in carrying by trailer and easy modal shift from vessel to intermodal modes.

\subsection{Coal Containerization}

This is the fully and perfect intermodal freight transfer from origin to destination and environment friendly. Recent establishment of coal based power plant in Bangladesh had attracted the buyer to import coal from abroad as local production is limited and uncertain for regular production of power. Although, container transportation model is applied for high value commodities, however, recent development of 
mega container ship also attracting to stuff low-value commodities like grain, coal etc. for fostering the scale and scope of containerized intermodal transportation rapidly [25]. In addition to tanktainer for liquid and petroleum, this is the innovation of handling of fuel at port and send via inland transport network. The significant contribution of this innovation is environmental factors and reducing multiple handling at port and shore that polluted the environment and misuse of commodities at loading and uploading points.

Emerging opportunity, Zhang and Pel [26] brought the synchromodal hinterland freight transport that yields economic, societal and environmental impacts and may add in the innovation of fuel handling at port. Mention that intermodal transport promoted promising solutions in retaining a sustainable transport system also catalyzing the economic growth and volume of freight transport brightly. Furthermore, to improve the efficiency, gaining competitiveness and achieving resilience against a changing environment, port needs to stay with the current age and search related innovations [22]. In the context of integration at port, it is concerned with the intermodality and organizational integration that undertaken by global carriers to respond against the requirements of industrial and commercial enterprises, at the same time, improving internal port efficiency to compete with another port nationally or regionally.

\section{Literature Review}

Ports are the prime element of transport management that linked with the national and global economy because of its relation with international shipping and global trade, overall, facilitator of international trade in a given supply chain. In a transport system, port is the important node in handling import export cargo \& container of a country either it is landlocked or having own port access naturally. Ports are acting as central hubs to transport raw materials for power generation and serve metropolitan areas also characterized by the geographical concentration of high-energy demand and supply activities as a consequence of the growing relevance of energy trades, public environmental awareness and a bigger industry focus on energy efficiency [27]. This literature review bought the related literature of port efficiency as well as efficient fuel handling and management at port where emphasized on the port success factors or CSFs to achieve the goal to support the nation and to do port transport business as playing supportive role to the neighbors as regional development. In addition, innovation and environmental issues are also explored to sustain in the competitive situation of port business and attract the users to receive the quality services in reduced cost in right time. Here, all literatures tried to connect with the port performance factor to facilitate the fuel import via Bangladeshi port and fuel handling and management efficiently to mitigate the growing demand of energy in Bangladesh.

Economic growth by industry and population growth both will demand the energy. Globalization of the world trade and increased volume of cargo \& container is highlighting the importance of shipping and logistics activities inevitably [28]. Port industry is highly internationalized and combined but a larger plethora of public and private stakeholders made an ideal field with a wide area of dynamic interaction [29]. Furthermore, port is the logistics center and port authority's social and business approach could be beneficial to all where port efficiency and performance helps to reduce the cost of port charges as well as shipping cost. In promoting the brand as equity, ports are facing challenges because of huge competition among the ports nationally, regionally and internationally [30].

Historically, port sectors are the source or center point of maritime logistics to produce port transport, therefore, innovation in the port is the prime activity to develop the industry in a profitable way [31]. As for context Bangladeshi ports and its future innovations to 
adapt with the world standard of port, this research specified the innovation that described by Taneja et al. [22]. In here, three types of innovations are stated for specific ports, preliminary, Incremental adaptation is called adaptive or efficiency innovation that is focusing the exiting port facilities. It offers to reduce cost per service, improves product and enhances the quality of the port services etc. Mongla port may choose this innovation because it is the planned innovation to follow the existing facilities of Chittagong port and develop accordingly. Just after, Evolutionary Innovation addresses existing or new issues with the state of the art approaches or techniques to target the new markets. It refers to distinctly better products and processes near to Incremental Innovation. This is suggested for main port Chittagong and newly established port Payra because it is also planned innovation to offer new business products within the existing facilities. At last, Revolutionary Innovation focuses on radically new and better ideas to transform or even dismantle the existing structure, technology or processes of the port or related organizations, lead to the discovery of new things innovatively. This is exclusively for Chittagong port because this is the unplanned innovation that recommended for Chittagong for thinking to serve the whole country and neighbors. Tuna and Duru [28] argued for sustainability and advised for formatting supply chain strategy in long term cooperations of port users, stakeholders in the distribution channels for improving the performance and efficiency. Environmental performance is an area that is affecting the technology in managing vessel handling activities at port especially in two sides-vessel operations for cargo handling and equipment handling for quick transfer of cargo and container by loading-unloading efficiently. Boardley [32] welcomes innovation in port sector in setting the latest equipment and technology for handling cargo and mitigate the demand to protect the environment as well as vessel discharge and loading operation in port.
Two important IMO (International Maritime Organization) [33] resolutions that are affecting the ports, one is related to the Maritime Environment Protection that guided to protect the interest of port and its outer limits, another is Maritime Safety that ensures the safety of sea by the Maritime Environment Protection Committee and Maritime Safety Committee respectively. Both the resolutions are important to handle fuel vessels at port, handling the cargo and its further loading to inland transport vehicle and must be ecofriendly and save to the environment. Concern of sustainability in shipping and logistics is increasing because of its involvement in a complex set of issues relating to social, environmental and economic aspects [30].

Traditionally, port academic literature always focused in improving port efficiency by resolving the conflict of stakeholders. Higher number of conflicts is the cause of poor performance and low productivity. On the contrary, resolutions of conflicts improve the port performance and increase the efficiency [34]. Port competitiveness affects the regions viability, prosperity and propensity for growth because ports play an important role in the region's economic development [35]. Raising the environmental concern, it is necessary for well-connected port infrastructure, efficient and reliable port services, in addition, to reduce the energy consumption in port [36]. Efficient cargo handling and hinterland connections are not the determinants of port competitiveness, it also requites to link in a given supply chain and depends on the availability of efficient infrastructure and inland connections as part of global supply chain [31].

The efficient fuel handling depends on the main performance of pilotage, towing \& pushing, unloading and storage and loading. Openness of a country offered to add in the global trade and economic activity where port access is important and needs to strengthen her port system in the context of sustainability [37]. In an integral part of transport and supply chain, role of port is to manage and coordinate 
the materials and information flow [31]. Due to conceptual framework in response the complexity of the port community in the process of creating value, port competitiveness is crucial and critical [38]. Overall, this literature review brought the necessity of handling fuel at the port and its further transportation to the final destination efficiently as derived demand of the users.

\section{CSFs in Port Management}

Gates [39] defined the CSFs where factors are the handful of key areas where organization must have to perform well on a consistent basis to achieve the mission \& vision arguably. Under the umbrella of strategic planning, CSFs are helping to develop the strategy with future scenarios that build the enterprise and indicate the processes for development.

CSFs are identified to appraise the value of the port and assess the performance in achieving the goal and target especially in handling and management of imported fuel in Bangladeshi ports. Based on the secondary resources and qualitative research findings, this research found some critical factors that analyzed to address the efficiency of ports in handling and management of fuel in Bangladesh.

\subsection{Port Productivity}

Port productivity depends on the PPIs (port performance indicators) that set by UNCTAD (United Nations Conference on Trade and Development) [40] and further described by De Lengen et al. [41]. They represented the characteristics of main PPIs which are cargo transfer product, logistics products and manufacturing products. Among them, cargo transfer product indicates the volume of cargo and container handling, value addition in port, investment level in port and modal shift of cargo \& container to the inland transport network. In addition, newly PPIs are added and described by De Lengen et al. [41] where vessel turnaround time, connectivity index also consumer benefits from lower transport cost. All are related with the port productivity and good port has the positive PPI in handling cargo and container. Maximum requirements of fuel are in urban cities and port cities. Recently, the trends of relocating the industry from inland to port/urban cities to make integrated connection

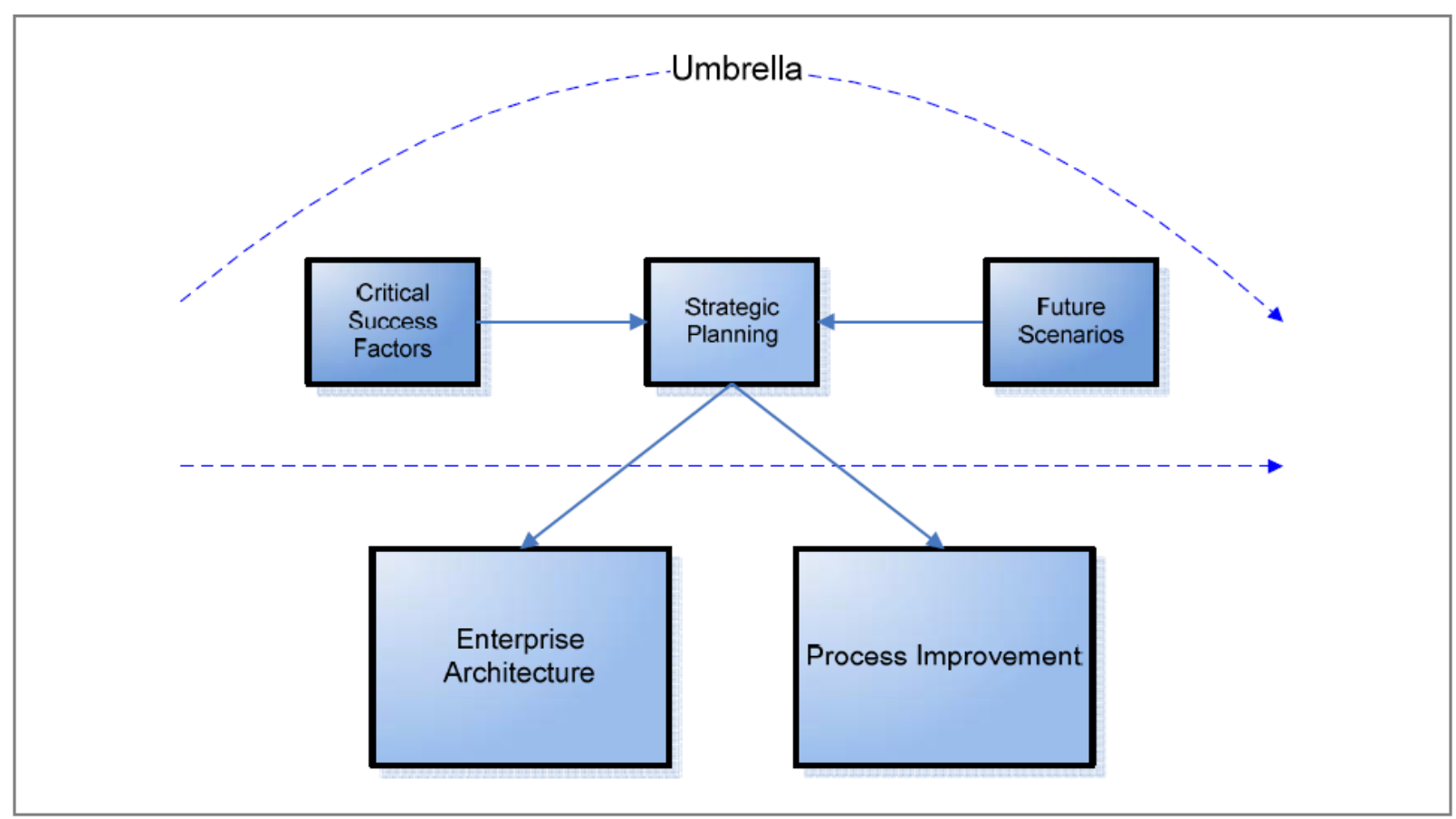

Fig. 5 Enhanced strategic planning in context [39]. 


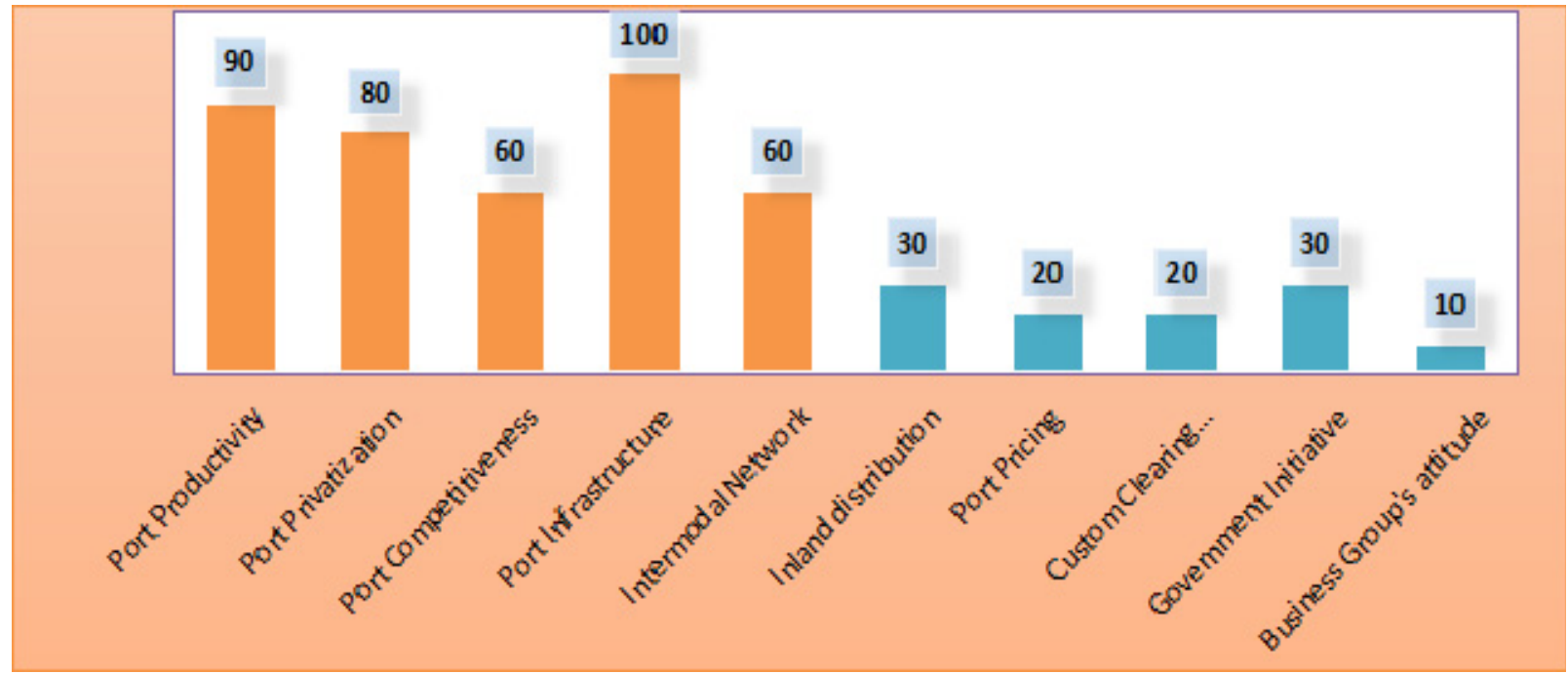

Fig. 6 Critical success factors in port development.

for getting the fuel facilities and shipment connection of raw materials and finished products timely and economically. Therefore, port authorities needs to provide the facilities of supplying fuel and handle the cargo \& container by applying the JIT (just-in-time) to increase the port productivity and effective logistics support. To validate the innovation performance in the port industry, it directed two thirds of efficiency and one third of product and process [22].

\subsection{Port Competitiveness}

Port competitiveness depends on the good hinterland connection, inland distribution, size of ships that bounded to change the port infrastructure, operations, multimodal and intermodal facilities of the port [21, 42]. In the Bay of Bengal, there are business rivalry that is unseen among the port of Bangladesh, India and Myanmar. China proposed the 21st century maritime Silk Road where Kolkata proposed for MLC (Maritime Load Center) in the Bay of Bengal where Chittagong port of Bangladesh is feasible in all context. Therefore, it is necessary to prove the competiveness of Bangladeshi port comparing with others ports. Even, Chittagong port has to prove its efficiency, productivity and hinterland facilities with other two national ports-Mongla and Payra. The complete transport chain including deep sea, feeder or lighter and inland transport assists to develop port supply chain and increase the port competitiveness in the maritime business rivalry. Besides port efficiency, the significant importance of developing strategies in the scientific way to provide best customer service in low cost in the framework of maintaining long term relation with the port users as competitiveness. In addition, technology is growing sense to play a bigger part in shipping [32].

\subsection{Port Infrastructure}

In perspective on CSFs, Aerts et al. [43] explored the provision of PPP in port infrastructure development. Port infrastructure serves a crucial facilitation role in the global supply chain for developing, upgrading or marinating the port's structure as well as hinterland oriented infrastructure of modes (road, rail and inland waterways or coastal shipping) and nodes (dry port, inland depot, off-dock, terminals) [43]. Furthermore, good infrastructure of port is treated as state of the art logistics center for a country to facilitate the import export trade. The significant structural changes in global logistics and shipping are catering the intermodal freight transportation system where port has to develop the strategy in the innovative way to change the inland transport infrastructure rapidly and actively. 


\subsection{Port Privatization}

Port performance indicator referred the privatization of ports in developing port infrastructure, installation of capital equipment, port pricing as well as increasing port efficiency. Public interests include economic growth, local industry development, and efficient port operations where private investment adds and looks for good return on capital and moving cargo in cheaper rate, faster in a manner that generates economies of scales [34]. To handover the risk of uncertainties that involved in the design, construction, maintenance and operations of the port and further infrastructure development, Aerts et al. [43] suggested to do the work by PPP. However, increasing participation of private sector in the port management and operations had generated the demand of port reforms [34]. Despite the port privatization for increasing the efficiency and infrastructural development, the research of Munisamy and Singh [35] found that Chittagong port of Bangladesh is government owned port that is efficient, self-sufficient and profitable organization in the Asia after Singapore. Moreover, now-a-day, Chittagong Port lets its hand establish port related infrastructure, inland and riverine container port also funding in the development of new port Payra in Bangladesh.

\subsection{Intermodal Network}

This is the new era of container or swap body transportation without multiple handling at port and other points also eco-friendly. Because of inland waterways road $\&$ highways and rail facilities with the port, there are good prospects of intermodal freight transportation in Bangladesh. To promote the intermodal network, Hanaoka and Regmi [2] counseled for the development of dry port and its intermodal connection. The growth of international trade and containerization in shipping demonstrated the need for improved intermodal network and it is very important for Asia as per trends of raw materials towards the industry [2]. Remarkably, intermodal transport helps to reduce the emissions of pollutants and having less environment impacts in the transport networks. And or, Montwill [44] argued for intermodals in developing fourth generation of port development where moving of container or swap body or tanktainer and modal shifting at port by efficient handling procedures set by integrated research on port development. He also defined the role of port as information center to update the users by stating the vessel, cargo and container position including the existence in the intermodal networks.

Even so, there are more CSFs in managing port like hinterland connections, custom clearing policy, political approach and others are important but not discussed fully in this section. Overall, CSFs will help to increase the port performance and work in the critical factors to overcome by the port authority.

\section{Qualitative Research Findings and Analysis}

The purpose of qualitative data for ensuring and identifying the key variables of the research title is to explore and receive responses from the expert in the specific field. By visiting the ports of Hong Kong, Bangladesh (Chittagong and Mongla) and studying the related literature from the secondary sources, direct interviews were conducted where 10 respondents delivered their qualified opinions and assisted to find out the innovations of maritime logistics regarding Bangladesh. Important dialogues were extracted from the interviews and summarized as bellows.

\subsection{Key Features of Bangladeshi Ports in Handling Fuel}

In the view of key features, all respondent were reflected that Bangladeshi ports are at strategic position in the Bay of Bengal to serve the region competitively. Historically, Chittagong port is well known to the world trader and has easy access in the Bengal for a long period. They are confident that ports 
are capable to cater the export import trade for timely releasing of cargo from the port and just time shipment of export items. From the beginning of the independency of Bangladesh, Chittagong and Mongla ports are handling the whole fuel that imported for industry and cooking purposes. Now-a-days, both ports have efficient manpower with latest equipment and technology in handling fuel. Most of the respondents were remarked that fuel supply by rail network is excellent besides container and passenger transportation by Bangladesh railway and it is profitable because of good connection among port, refinery and fuel points. In addition, they highlighted the role of waterways in transporting fuel from port to inland oil depot by oil tanker that is cheap and environment friendly transportation in Bangladesh. Fortunately, Bangladesh has the natural inland waterways and river terminal all over the country to facilitate the inland distribution of fuel and well-accessed with the ports and only refinery in Chittagong that is located nearby major port Chittagong.

\subsection{Competitive Advantages of Bangladeshi Ports}

Connectivity is a great issue for South Asia exclusively for latest consortium BBIN (Bangladesh, Bhutan India, and Nepal) especially for highway and river connectivity that features the regional connection among the Bangladesh, Bhutan India, Nepal, and Myanmar and South-West part of China. Remarkable, geographical position of Bangladesh nearest the Bay of Bengal and natural presence of rivers in Bangladesh are attracted by all. In this situation, Bangladesh is not only a lucrative place in South Asia but also for world traders and investor to take the opportunities of low labor wages, efficiency of South Asian people for their manpower and others. With much talk about the highway and river connectivity within the BBIN, Bangladesh is in strategic place who is the prime logistics provider to develop the BBIN countries industry and supply the port transport in the process of easy logistics solution. Arguably, Bangladesh is not a position to serve the neighbors by providing transport service because of infrastructure, policy and operations strategy that will contribute the development of the region. We, as Bangladeshi, need to understand our current position and what we will put for our next generation. It is not a matter of speed, political understanding, or supporting the neighbors for mitigating their demand and sustainability wherever it is a matter of our soul interest and doing transport business with others by developing road and highways, river and rail where Bangladesh is the primary source in the region for providing port transport to the neighbors as maritime port transport business in the region expectantly.

\subsection{Port Productivity and Enhancing the Capacity}

Maximum respondents were argued for utilizing the excess capacity of Mongla Port. In addition, it is essential to enhance the capacity of Chittagong port in fuel handling. In this connection, it was suggested to create exclusive anchor zone in the outer limit of Chittagong port as reserve anchorage of fuel vessels that will discharge to the lighters without any congestion or avoiding draft restriction to entrance to the port jetty or terminals. Approx. 50\% respondents were reflected on the capacity of Mongla port and advised to the government for international marketing of this port or lease to international terminal operator by which Mongla port will play a good role in sharing the pressure of Chittagong port dynamically. However, all are discussed about the port productivity and stated that government has to assess the port future plan and identify the critical factors that will indicate where port or government has to work to enhance the capacity.

\subsection{JIT and Intermodal Freight Transportation System in Bangladesh}

JIT approach is emphasized by the respondents where they argued for readiness of lighter vessel for 
avoiding the delay of mega vessel at sea. Just after, they opinioned that there is no alternative approach of practicing JIT approach in fuel handling because port has to handle mega vessel and to reduce the cost, vessel has to clear at port as early as possible.

On the other hand, to describe the intermodals in fuel handling, all were feared about the costing and possibilities of congestion at road \& highways but appreciated the initiative to follow the latest edition of freight transportation system as it is environmental friendly. Furthermore, they advised to use container for coal handling and send the container to the intermodal network.

\subsection{Critical Success Factors}

All respondents were argued for port infrastructure because they feel that existing port infrastructure is not up to the mark and not in world standard and they connected the port privatization is important for developing standard port infrastructure. However, $20 \%$ were disagreed for privatization and provided the example of Chittagong port which one is profitable governmental organization of the world.

\subsection{Innovations or Innovative Idea in Fuel Handling and Management at Port}

This qualitative study found some innovations that are prescribed by the respondents as bellows:

- Dedicated rail track for supplying fuel wagon or box from port/refinery to inland destinations in the major cities. In addition, establish new rail track from ports to major cities only for fuel transportation.

- To develop intermodal network for coal transportation from port jetty to power plant or any other places.

- Establish new oil refinery nearby Mongal and Payra port for decreasing the dependency on governmental Eastern Refinery Limited in Chittagong.

- Dedicated wings for port and customs to handle the fuel terminals at ports and inland terminals in selected place to cover the whole country.

\subsection{Suggestions for Further Development}

Most of the respondents suggested to abolish the power of governmental organization BPC to control the fuel sector for general purposes and it will be better to open the import opportunity to the business person privately. Furthermore, CPA has to take initiative to construct specialized terminal in fuel handling even they may help Mongla and Payra port by financing and providing skilled manpower to operate the port also technical assistance in fuel handling and management at port. In addition, considering the upcoming volume of fuel (LPG, LNG and coal), government needs to think and explore about the deep port for bringing mega vessel to reduce the ocean freight arguably. Furthermore, it is suggested to take initiative by government to open the Mongla port to the neighbors to use the unutilized capacity of the port especially in handling fuel and intermodal POL containers and tanktainer. Overall, port development is advised by all to mitigate the demand of fuel and other cargo \& containers skillfully.

Overall, qualitative research findings and analysis, literature review and other studies in this paper are indicating the good establishment of government or port authorities in Bangladesh for handling fuel in ports where upcoming infrastructure development in terminal construction exclusively for oil, LPG, LNG and coal handling will help to mitigate the demand of fuel handling port. However, continuous development is appreciated in human resource, equipment and technology development to keep the efficiency always.

\section{Conclusion}

In a given supply chain, the hustle and bustle of a port is dedicated in the aim of bringing vessels, loading and unloading cargo and containers efficiently and arrange to transfer the cargo and container as modal shift as quickly as possible. In addition, port has to develop strategies and evolve the infrastructure 
to accommodate the growing volumes of freight and fulfill the obligations as an economic common ground with businesses and environmental interest groups [14]. Ship owners always favor to stay shorter time in port that indicates the shorter time in handling cargo and this is very crucial in fuel handling because of its quick transfer to the refinery, oil depot or plants by using JIT approach. Port industry is facing great concern of environmental sustainability where technological or organizational innovation can provide solution which also fits dynamically port actors' demands and the port institutional environment stands a chance to succeed [45].

This research aimed to describe the current situation of Bangladeshi ports in handling imported fuel and further distribution to consignee efficiently and timely also stated the export status of fuel residues Naphtha and others. Furthermore, in here, research found the innovation in managing fuel to supply the major cities/power plant/refueling points that located all over the country by multicore pipeline, intermodal container or tanktainer. In addition, it is essential to form a larger collaboration approach to implement PPP to privatize the fuel sector and port terminal establishment to increase the port productivity. In the aim of serving energy against the demand of industry, domestic's households and transport, Bangladesh needs to develop integrated supply chain system of fuel from the port, in addition, to do port transport business of fuel with India, Nepal and Bhutan regionally and with Myanmar and China internationally by using the geographical advantages of Bangladeshi ports.

To sum up, port governance and competiveness are two important foresights in staying with the business rivalry of port business in the South Asian region and must be streamlined to allow flexibility to the port users in choosing ports. Relatedly, port and transport mode infrastructure development is connected with the port privatization that will allow to improve the port efficiency and increase the port productivity. The productivity of Bangladeshi ports and continuous development of transport modes, infrastructural development are creating the opportunity to serve the nation endlessly and assist neighbors to take maritime logistics access from Bangladesh to mitigate their own demand and establish industry to do international business. Now, it is the time of integration among the Bangladeshi ports for increasing the facilities to enhance the capacity and efficiency exclusively in handling fuel for mitigating the energy demand of the country and the region.

Finally, port authorities can play an important role in the process of inland distribution a and found greatly from the literature of innovation regarding port, maritime logistics and port transports especially some innovations of Rotterdam port [22] that will help to develop maritime logistics industry of Bangladesh in future to handle the fuel efficiently. Nevertheless, the present contribution in this research has lacking in further theoretical soundness, data validity and wider field testing. It was not possible to take current data from the sources that identified preliminarily and minimum response in the qualitative research was received. Lastly, innovations and CSFs that are identified in this paper will help to handle the fuel in Bangladeshi ports competently in the view of JIT.

\section{Future Directions}

Research brought some future directions to the reader, policy makers, government and others by which Bangladesh may develop their maritime logistics transport industry in the light of innovations and way of increasing the efficiency and productivity of ports to stay with the competition of port world. As power and energy are the main barriers in industrial development as well as to provide required daily life requirements, Bangladesh must to import fuel and need to enhance the port capacity at any cost for maritime logistics industry.

- PPP helps to split the cost and risk in the phase of new port development. Privatization of bulk liquid 
and coal terminal through PPP is essential under the port authorities in Bangladesh.

- Commercial import licenses for POL to open the business and marketing by the private owner that will decrease the dependency to BPC and fuel will be available to all in a minimum rate of fuel.

- Gibson [14] added that financially healthy ports are always considering ways to handle capacity challenges and promote productivity. In here, the forward-thinking port that can balance multiple parties' interests and see itself as an expert in strategy in addition to being an expert in cargo-handling will succeed when faced with capacity challenges where port needs to quantify the strategy into equipment, infrastructure and operating improvements. Chittagong Port needs to help other ports in developing port infrastructure also inland distribution centers to make integrated logistics network for supplying cargo and container.

- Open the door of maritime load center of Bangladeshi ports to the neighbors in the forum of BBIN and BCIM (Bangladesh, China, India, Myanmar). Furthermore, negotiate with the Maritime Silk Road authority to select Chittagong Port and regional maritime load center in the Bay of Bengal.

- Strengthening the rail network to transfer the fuel Box, fuel wagon or tanktainer from the port to urban cities by dedicated rail track also offer the rail transit or transshipment to the neighbors as intermodal rail networks to do port transport business.

- To create the maritime commission to monitor the port authority, private terminal operators and related stakeholder's activities and fix the freight and expenditure as per international port pricing. In addition, commission has to fix the transit and transshipment cost for neighbors.

- Port authority has to investment in research works to find out the innovations and other factors for improving the port efficiency and productivity.

- Government may take a plan to connect the power plants with the port authorities and define or make integrated supply chain network for receiving the fuel from the port easily and in a reduced cost.

- Exchange the competent workforce of Chittagong port to Mongla/Payra port and share the lesson learning \& best practice of all port internally for making operation plan, marketing strategy, port pricing and future business plan.

- Involve and engage international fuel terminal operators in the planned terminals at Maheshkhali, Kutubdia Island and Payra port for handling mega tanker, LPG/LNG carrier and coal vessels efficiently and timely. Need to take extra care for Uranium fuel for supplying to the nuclear power plant.

\section{Acknowledgments}

This research is acknowledging the sincere cooperation of my lovely wife POMPA SAHA who inspired to write about fuel handing in Bangladeshi seaports and its further distribution to all over the country and helped to collect data and in conducting qualitative research interviews from December 072015 to January 10, 2017. This paper was presented at the International Conference on Maritime Energy Management (MARENER 2017) at Malmo in Sweden on January 24-25, 2017, organized by World Maritime University.

\section{References}

[1] Graham, G. 2008. "Understand Innovation in 5 Minutes." Web. Accessed June 06, 2016. http://www.slideshare.net/Brokenbulbs/understand-innov ation-in-5-minutes?qid=0ebc0045-fb4a-4207-8615-d1c12 $1717 \mathrm{f0e} \& \mathrm{v}=\& \mathrm{~b}=\&$ from $\mathrm{search}=3$.

[2] Hanaoka, S, and Regmi, M. B. 2011. "Promoting Intermodal Freight Transport through the Development of Dry Ports in Asia: An Environmental Perspective.” IATSS Research 35: 16-23.

[3] Neuman, W. L. 2011. Social Research Methods: Qualitative and Quantitative Approaches. Essex: Pearson Education Limited.

[4] Allate, B. M. 2015. "Shipping Management and Logistics Innovation: Key Factors for Success." International Journal of Management Science and Business Administration 2 (1): 50-5. 
[5] Kumar, C. R. 2008. Research Methodology. New Delhi: APH Publishing Corporation.

[6] BPC. 2016. "Imported Petroleum Products." Web. Accessed December 12, 2016. http://www.bpc.gov.bd/contactus.php?id=46.

[7] CPA. 2016a. "Introduction: Chittagong Port Authority." Web. Accessed June 14, 2016. http:/Cpa.Gov.Bd/Introduction-Chittagong-Port-Authority/.

[8] CPA. 2016b. "Overview 2015-2016: Chittagong Port Authority." Web. Accessed January 18, 2017. http://www.cpa.gov.bd/site/page/6c321441-c120-4ee7-b7 a5-3543b5058d0d/CPA-Overview.

[9] ADB. 2015. Connecting South Asia and Southeast Asia. Tokyo: ADB Institute.

[10] Mongla Port. 2016. "The Future Prospect and Potentials of Mongla Port Specially after Completion of the Padma Bridge.” Web. Accessed December 01, 2016. http://www.mpa.gov.bd/bn/benefit.

[11] Payra. 2016. "Welcome to Payra Port Authority." Web. http://ppa.gov.bd/welcomepost/welcome-to-payra-port-au thority/.

[12] PICT. 2016. “About." Web. Accessed December 01, 2016. http://pict.gov.bd/about.

[13] Chittagong Custom House. 2016. "Listed Off-dock at Chittagong Custom House." Web. Accessed June 14, 2016. http://chc.gov.bd/imp/offdock.php.

[14] Gibson, C. 2016. "Strategy at Seaports Is Key to Handling Capacity Challenges." Web. Accessed December 06, 2016. http://www.aapaseaports.com/ index.php/2016/09/21/strategy-at-seaports-is-key-to-hand ling-capacity-challenges/.

[15] WEC. 2017. “Global Transport Scenarios 2050.” Web. Accessed January 01, 2017. https://www.worldenergy. org/wp-content/uploads/2012/09/wec_transport_scenarios 2050.pdf.

[16] Imam B. 2016. "Dependency on Imported Energy Source.” Web. Accessed December 01, 2016. http://energybangla.com/dependency-on-imported-energy -source/\#print.

[17] Indexmundi. 2016. "Bangladesh Import." Web. Accessed December 01, 2016. http://www.indexmundi.com/ energy/?country=bd\&product=coal\&graph=imports.

[18] MOF. 2016. "Power and Energy Sector Road Map: An Update." Web. Accessed December 09, 2016. http://www.mof.gov.bd/en/budget/11_12/power/power_e nergy_en.pdf.

[19] Saha, R. C. 2016. "Innovation in Maritime Logistics Industry of Bangladesh for Doing Port Transport Business." Conference Proceedings of International Conference on Business Management, Economics and Social Sciences, Jointly Organized by AMDISA
(SAARC Body), Uttara University (Bangladesh) and GBMF (USA) on December 21-23, 2016, Dhaka, Bangladesh.

[20] Dash, K. C. 2008. Regionalism in South Asia: Negotiating Cooperation, Institutional Structures. New York: Routledge.

[21] Saha, R. C. 2015. "Port Development in Bangladesh." European Journal of Business and Management 7 (7): 392-9.

[22] Taneja, P., Vellinga, T., and Schuylenburg, M. V. 2012. "Ports and Innovation." Proceedings of the World Conference on Transport Research Society (WCTRS), on June 21-22, 2012, Antwerp, Belgium.

[23] Karim, M. A. 2015. “China's Proposed Maritime Silk Road: Challenges and Opportunities with Special Reference to the Bay of Bengal Region." Pacific Focus December 2015. DOI:10.1111/pafo.12059.

[24] Lagoudis, I. N., Rice Jr, J. B., and Salminen, J. B. 2014. "Port Investment Strategies under Uncertainty: The Case of a Southeast Asian Multipurpose Port." The Asian Journal of Shipping and Logistics 30 (3): 299-319.

[25] Yang, D., Weng, J., and Hu, J. 2016. "Coal Containerization: Will It Be an Alternative Mode of Transport between North and South China in the Future?" Maritime Business Review 1 (1): 76-87. http://dx.doi.org/10.1108/MABR-03-2016-0001.

[26] Zhang, M., and Pel, A. J. 2016. "Synchromodal Hinterland Freight Transport: Model Study for the Port of Rotterdam.” Journal of Transport Geography 52: 1-10.

[27] Acciaro, M., Ghiara, H., and Cusano, M. I. $2014 \mathrm{a}$. "Energy Management in Seaports: A New Role for Port Authorities." Energy Policy 71: 4-12. http://dx.doi.org/10.1016/j.enpol.2014.04.013.

[28] Tuna, O., and Duru, O. 2013. "Current State and Future of Shipping and Logistics." The Asian Journal of Shipping and Logistics 29 (2): 121-4.

[29] Dooms, M., and Parola, F. 2016. "Port Management Studies." The Asian Journal of Shipping and Logistics 32 (1): 1-2.

[30] Yip, T. L. 2014. "Sustainability in Shipping and Logistics." The Asian Journal of Shipping and Logistics 30 (3): 345-7.

[31] Carbone, V., and De Martino, M. 2003. "The Changing Role of Ports in Supply-Chain Management: An Empirical Analysis." Maritime Policy \& Management 30 (4): 305-20.

[32] Boardley, T. 2015. "Lloyd's Register: Technology Will Play a Bigger Part in Shipping." Web. Accessed June 12, 2016.

http://splash247.com/moving-toward-cleaner-fuels-compl ications-controversy-confusion/.

[33] IMO. 2016. "Marine Environment: Reception Facilities." 
Web. Accessed December 07, 2016. http://www.imo.org/en/OurWork/Environment/PortRecep tionFacilities/Pages/Default.aspx.

[34] Galvao, C. B., Wang, G. W. Y., and Mileski, J. 2016. "Public-Private Interests and Conflicts in Ports: A Content Analysis Approach." The Asian Journal of Shipping and Logistics 32 (1): 13-22.

[35] Munisamy, S., and Singh, G. 2011. "Benchmarking the Efficiency of Asian Container Ports." African Journal of Business Management 5 (4): 1397-407.

[36] Boile, M., Theofanis, S., Sdoukopoulos, E., and Plytas, N. 2016. "Developing a Port Energy Plan: Issues, Challenges and Prospects." Journal of the Transportation Research Board 2549: 19-28. DOI: 10.3141/2549-03.

[37] Ghosh, B., and De, P. 2001. "Indian Ports and Globalisation: Grounding Economics in Geography." Economic and Political Weekly 36 (34): 3271-83.

[38] De Martino, M., and Morvillo, A. 2008. "Activities, Resources and Inter-organizational Relationship: Key Factors in Port Competiveness." Maritime Policy \& Management 35 (6): 571-89.

[39] Gates, L. P. 2010. "Strategic Planning with Critical Success Factors and Future Scenarios: An Integrated Strategic Planning Framework." Web. Accessed June 07, 2016. http://repository.cmu.edu/cgi/viewcontent.cgi? article $=1419 \&$ context $=$ sei.

[40] UNCTAD. 1976. "Port Performance Indicators." Web. Accessed December 03, 2016. http://unctad.org/en/PublicationsLibrary/tdbc4d131 sup1re v1_en.pdf.

[41] De Langen, P. W., Nijdam, M., and Van der Horst, M. 2007. "New Indicators to Measure Port Performance." Journal of Maritime Research I (IV): 23-56.

[42] De Langen, P. W., and Pallis, A. A. 2006. "Analysis of the Benefits of Intra-port Competition." International Journal of Transport Economics 33 (1): 69-85.

[43] Aerts, G., Grace, T., Dooms, M., and Hazendonck, E. 2014. "Public-Private Partnership for the Provision of Port Infrastructure: An Explosive Multi-actor Perspective on Critical Success Factor." The Asian Journal of Shipping and Logistics 30 (3): 273-98.

[44] Montwill, A. 2014. "The Role of Seaports as Logistics Centers in the Modeling of the Sustainable System for Distribution of Goods in Urban Areas." Procedia-Social and Behavioral Sciences 151: 257-65.

[45] Acciaro, M., Vanelslander, T., Sys, C., Ferrari, C., Roumboutsos, A., Giuliano, G., Lam, J. S. L., and Kapros, S. 2014b. "Environmental Sustainability in Seaports: A Framework for Successful Innovation." Maritime Policy \& Management 41 (5): 480-500. 


\section{Appendix A: Research questionnaire}

From the experience of visiting local and international ports from December 2015 to June 2016, this research developed below questionnaire and worked with the respondents:

1. What are the key features of Bangladeshi seaports in handling fuel to mitigate the domestics demand and serve the neighbors regionally and internationally?

2. What are the competitive advantages of Bangladeshi Seaports with other regional ports?

3. To mitigate the power and energy requirements for industry and household uses, Bangladesh is going to import Coal, Oil, LPG, LNG and other fuels as raw materials or fuel commodities in big volume. Do you think that ports are able to handle this big volume or country needs to improve the port productivity and enhance the capacity of existing port?

4. Do you think that JIT (just in time) approach will help to quick transfer of fuel from mega vessel to inland fuel depot/consignee premises directly or apply the Intermodal Freight Transportation system for efficient fuel handling and management at port?

5. What are the CSFs (critical success factors) of a seaport regarding Bangladesh?

6. Do you have any innovative idea or refer any innovation that will help to faster fuel handling and management at port?

7. Any suggestion from your end to develop our seaport and port transport industry. 
Appendix B: List of the respondents in the qualitative survey

\begin{tabular}{lllll}
\hline SL No. & Code & Designation and others & Country & Remarks \\
\hline 01 & A & Policy researcher & Bangladesh & Direct interview \\
02 & B & PhD Researcher in transport management & Bangladesh & Direct interview \\
03 & C & Port specialist & Hong Kong & Telephonic interview \\
04 & D & Owner of shipping company-local & Bangladesh & Direct interview \\
05 & E & Port transporter & Bangladesh & Telephonic interview \\
06 & F & University teacher & UK & Telephonic interview \\
07 & G & Manager (training)-port authority & Bangladesh & Direct interview \\
08 & H & Port user and stakeholder & Bangladesh & Direct interview \\
09 & I & Seafarer and port consultant & Bangladesh & Telephonic interview \\
10 & J & University teacher & Bangladesh & Telephonic interview \\
\hline
\end{tabular}

